\title{
MANAGEMENT PRACTICES, WELL-BEING AND SUPPORTIVE BEHAVIOR
}

\author{
ELAINE R. NEIVA ${ }^{1}$ \\ (iD) https://orcid.org/0000-0003-0503-3234 \\ MAGNO O. MACAMBIRA ${ }^{2}$ \\ (iD) https://orcid.org/0000-0002-6453-3020 \\ ELISA M. B. A. RIBEIRO 3 \\ (D) https://orcid.org/0000-0002-4550-454X
}

To cite this paper: Neiva, E. R., Macambira, M. O., \& Ribeiro, E. M. B. A. (2020). Management practices, well-being and supportive behavior. Revista de Administração Mackenzie, 21(1), 1-27. doi:10.1590/1678-6971/eRAMD200098

Submission: May 26, 2019. Acceptance: Sept. 11, 2019.

1 Universidade de Brasília (UnB), Brasília, DF, Brazil.

2 Universidade Estadual de Feira de Santana (UEFS), Feira de Santana, BA, Brazil.

3 Universidade Salgado de Oliveira (Universo), Niterói, RJ, Brazil.

\section{(cc) BY




\section{ABSTRACT}

Purpose: The aim of this paper was to evaluate the influence of change management practices, reasons to change and anticipated benefits on well-being and change-supportive behavior.

Originality/value: The theoretical contribution of this study is giving support to measure management interventions and measuring the meanings individuals attribute to the process of change.

Design/methodology/approach: The study included 255 employees from a Brazilian holding company that offers road transportation, charter, and logistics services in three Brazilian states. The following measures were used: Change Management Practice Scale, Scale of Reasons and Benefits for Change, Change-Supportive Behavior Scale, and Well-Being at Work Scale. The instruments were applied to professionals and managers to evaluate the proposed measures considering the undergoing process of organizational change. The sample data were submitted to exploratory factor analysis (EFA) and Confirmatory Factor Analysis (CFA) of the instruments, as well as mediation analysis and Structural Equation Modeling to test the hypotheses.

Findings: The study results indicate that change management practices positively affect both supportive behaviors and workers' well-being. A differentiated effect of perceived organizational reasons and perceived benefits on supportive behaviors and well-being at work was also identified.

\section{KEYWORDS}

Change in organizations. Management practices. Workers' well-being. Reasons and benefits for change. Change-supportive behavior. 


\section{INTRODUCTION}

Organizational change can be characterized as a set of changes in organizational components, whether they are intentionally triggered by interventions that have consequences on the results of the organization and members (Neiva \& Paz, 2012; Woodman, 2014). The authors also emphasize the need for monitoring and evaluating this process to prevent damaging consequences for the members of the organization (Neiva \& Paz, 2012). The deliberate and conscious use of strategies, systematic methods and knowledge to ensure that the organization changes towards desired outcomes while ensuring effectiveness are essential characteristics of this process (Davis \& Holland, 2002; Hayes, 2002, 2007), which still aims to favor positive reactions in terms of employee behavior and well-being (Vakola, 2016).

The manifestation of behaviors in support of organizational change is the most desired positive reaction by companies (Kim, Hornung, \& Rousseau, 2011), which makes manifestation a critical aspect for the success of changes (Vakola, 2016). Support for organizational change can be defined as behaviors that are consistent with the goals of change (Vakola, 2016), i.e. supportive behavior is one that an employee actively participates in, facilitating and contributing to the planned change initiated by the organization (Kim et al., 2011).

There are several constructs that address employee responses to the process of change, yet few directly address behavioral responses (Kim et al., 2011). Members of the organization can commit or support organizational change because they want to (value change), because they have no other alternative (few options), or because they must (are required to). Responses based on "wanting" represent the highest level of commitment and support for organizational change (Herscovitch \& Meyer, 2002). Three dimensions of behavior can be conducive to change: compliance, cooperation, and support (Hercovith \& Meyer, 2002). Compliance refers to the willingness of employees to do what is required by the organization to implement change. Cooperation refers to the acceptance of the "spirit of change" and willingness to make it work. Finally, support refers to the employees' willingness to accept change and "sell" it to others (Hercovith \& Meyer, 2002).

In situations of organizational change, employees seek to make sense of change, supported by a subjective view and their values, which together inform their response to organizational change (Lysova, Richardson, 
Khapova, \& Jansen, 2015). This supportive response to change can be driven by several factors, including perceived career opportunity and understanding of change initiatives (Lysova et al., 2015). The way the organization handles the processes of change (Carter, Armenakis, Feild, \& Mossholder, 2013), the participation of managers during the process of implementation of change, employees' assessment of the program, and their perceptions regarding the usefulness of intervention are factors that facilitate behaviors that support organizational change (Carter et al., 2013; Lysova et al., 2015). Intervening so that individuals understand the opportunities of change initiatives, delivering positive responses to the process, and ensuring the organization changes toward desired outcomes, ensuring effectiveness, are essential characteristics of this process and the cornerstones of organizational change management.

\section{ORGANIZATIONAL CHANGE MANAGEMENT}

The term organizational change is dynamic, and it involves a range of interventions, human actions, communication activities, and interactions. Thus, organizational change can be characterized as a natural, nonlinear interactive process (Jian, 2011; Schreyögg \& Sydow, 2011), as it can evolve into both progressive and retrograde movements (Woodman, 2014). However, the literature always raises possible leadership control and monitoring (Burke, 2011; Woodman, 2014), which refers to the possibility of planning, controlling and monitoring human action and employee reactions to the processes of change (Hayes, 2007; Rao, 2015) by using deliberate and conscious strategies, systematic methods to ensure that the organization changes towards desired outcomes and ensure their effectiveness (Hayes, 2007; Rao, 2015). According to some authors, the goal of organizational change management is to reduce the inevitable drop in productivity that is a consequence of the processes of change (Morin et al., 2016). According to others, avoiding resistance to change seems to be the great purpose of management, that is, management skill is most needed (Battilana, Gilmartin, Sengul, Pache, \& Alexander, 2010; Hayes, 2007). Some authors point out that organizational change management must be understood in terms of practices (Jansson, 2013; Raineri, 2011; Rao, 2015). People's acceptance of what is being proposed during the process of change, appropriate use of incentive systems, focus on technology, learning, team building and leadership, commitment to organizational goals, vision and 
strategy, and shared communication about change lead to short-term victories (Sande, Walela, \& Wamukoya, 2015) because they correspond to subjects' beliefs and provide a clear idea of where to be in the next phase (Rao, 2015). Changes in management practices are ways managers have found to achieve the above-mentioned purposes.

\section{ORGANIZATIONAL CHANGE MANAGEMENT PRACTICES}

The term practice has many definitions. It may mean "materially embodied and mediated arrangements of human activity centrally organized around practical and shared understanding" or "connected, shared, and implicit ways of understanding, speaking, and doing things" (Whittle, Suhomlinova, \& Mueller, 2010, p. 31). There is very little consensus on which practices are specific to change management (Jansson, 2013). Although the relevance of the content and context of organizational change is acknowledged among scholars, a dominant assumption seems to be that these practices are universal in nature (Jansson, 2013; Kotter, 2000). A second assumption is that resistance is a result of change (Levay, 2010), that is, a natural phenomenon due to the process. For example, a vast 60 -year review of quantitative studies on reactions of organizational change (Oreg, Vakola, \& Armenakis, 2011) shows that studies focusing on reasons for resisting change and how to affect resistance are minimal.

Practices are dimensions of activity in the socially constructed context, such as rules, tools, methods, meetings, social and discursive practices (Jansson, 2013), leadership actions, planning methods, functioning of processes, strategies, personal engagement, conflict management and communication practices (Sande et al., 2015; Stensaker \& Langley, 2010; Stensaker \& Meyer, 2012). Change management practices can also be characterized as a "set of organizational interventions that, when properly implemented and consistent with internal and external organizational events, facilitate the approval of organizational change processes" (Raineri, 2011 , p. 226). Although there is a wide range of literature offering advice on management change for professionals, five practices (diagnosis and organizational alignment, leadership, communication and compensation/ incentive, training) are more frequent in the studies on the subject (Raineri, 2011). Diagnosis and organizational alignment identify the need or preparation for change, which are also called diagnosis and analysis (Buchanan et al., 2005; Kotter, 2000). Leadership, in turn, addresses the 
leader's understanding and performance required to change so that his/her subordinates may also commit to change (Battilana et al., 2010; Kotter, 2000). Communication is the third practice because it allows us to understand what, when and why the organization is changing, which facilitates acceptance and adaptation of new circumstances, from a strategic to an operational level (Afande, 2015; Levay, 2010; Kotter, 2000). The last two change management practices are compensation/incentive, which aims to reinforce desired behaviors during the process of change through compensation or benefits (Afande, 2015; Kotter, 2000), and training, which prepares employees for the change (Pearce \& Sims, 2002). Considering the arguments above, our first hypothesis of this study is:

- Hypothesis 1: Change management practices are positively associated with supportive behavior for change.

\section{PERCEPTION OF REASONS AND BENEFITS FOR ORGANIZATIONAL CHANGE}

Most theories assume that people use some type of rational measurement or utility maximization in the pursuit of their own interests (Schwandt, 2005). The model of change-supportive behavior is also based on rationality and planned behavior (Kim et al., 2011), since it considers that individuals are motivated to comply with an object or process when situations or actions offer benefits that meet individual interests (Vakola, 2016).

The process of "sensemaking" is based on prior knowledge to assign meaning to new information, and it is facilitated by schemas (Bartunek, Rousseau, Rudolph, \& Depalma, 2006), which reduce the complexity of the information received and allow the association between actions and past meanings (Schwandt, 2005). This association facilitates the understanding of the process of change and gives meaning to the process experienced by the individual. Reasons for change involve creating a purpose or "making sense" of change that helps members accept the need for change (Kim et al., 2011; Vakola, 2016) as they help the process of change make sense; the reasons or "meanings" for the process may be related to the positive reactions of individuals during the process of change (Vakola, 2016). Recipients can also measure organizational change in terms of their own perceived or anticipated gains (Kim et al., 2011; Vakola, 2016) or losses as change may or may not influence the quality of some aspects of their work or professional 
life (Vakola, 2016). Anticipated benefits of change refer to the expected results of change with personal valence of employees (Kim et al., 2011; Oreg et al., 2011; Vakola, Armenakis, \& Oreg, 2013).

Organizational members value organizational change for different reasons: they value change, assess its need, perceive benefits or whether it is "worth it" (Weiner, 2009), which suggests valence of organizational changes for individuals. The valence of organizational changes can be formed by extrinsic components (rewards, benefits) as well as intrinsic components - autonomy, achievement, satisfaction (Oreg et al., 2011; Vakola et al., 2013). When valence of change becomes positive, it can be influenced by the perception of the benefits of change that are related to favorable reactions to the process (Kim et al., 2011).

In general, practices used for management during the organizational change process can contribute to the reasons and benefits for change among employees, which in turn influence behaviors, relationships among individuals during the processes of change and well-being at work. Understanding reactions to organizational change is a critical aspect for successful change (Bartunek et al., 2006; Oreg et al., 2011; Vakola, 2016). There are several studies in the literature on attitudes related to the implementation of change, such as readiness for change (Puspasari, Sukmawati, \& Sumertajaya, 2017; Weiner, 2009), openness to change (Cunningham, 2006), and behaviors of resistance to change (Oreg et al., 2011), but few studies investigate behavioral responses supporting change (Kim et al., 2011; Nery \& Neiva, 2015). These arguments lead us to the second hypothesis of the study:

- Hypothesis 2: The reasons for change and the perceived benefits of change are positively associated with supportive behavior for change.

\section{ORGANIZATIONAL CHANGE, SUPPORTIVE BEHAVIORS, AND WELL-BEING AT WORK}

Using productivity and results indicators alone do not cover the human aspect of the organizational change process (Neiva \& Paz, 2012; Oreg et al., 2011), since the organizational change processes cause affective, cognitive and behavioral reactions (Vakola et al., 2013) that can be understood by evaluative theories that address the relationship between cognition-emotionbehavior (Fugate, Harrison, \& Kinick, 2012). The evaluative theory of emotion, for example, is based on the proposition that individuals evaluate 
their environments and these assessments cause emotions, which are often associated with longer lasting affective states (Fugate et al., 2012). Reasons to change and perceived benefits can contribute to the positive or negative assessment of change and have consequences on the employees' well-being (Bryson, Barth, \& Dale-Olsen, 2013; Dahl, 2011; Fugate et al., 2012).

Research shows that individuals often evaluate organizational change negatively - as harmful or threatful (Fugate, Kinicki, \& Prussia, 2008). Negative effects on the well-being of organizational change are associated with job uncertainty and loss (Green, 2011), worker overload and stress (Dahl, 2011), and increased anxiety (Bryson et al., 2013). Well-being comprises affective and cognitive aspects experienced in relation to work and it can be influenced by organizational change. The implementation of organizational changes is related to the context in which the changes occur, the cognitive traits that the individual uses to interpret them and the opinion of others about the process (Dahl, 2011; Green, 2011).

Some types of change, such as downsizing, influence employee wellbeing, such as increased turnover (Fugate et al., 2012; Rafferty \& Restubog, 2010), high levels of burnout, cortisol, testosterone, and low rates of wellbeing, stress, cardiovascular complaints (Dahl, 2011), absenteeism (Burke \& Greenglass, 2000; Cunningham, 2006), psychosomatic complaints (Burke \& Greenglass, 2000), and other types of illness (Dahl, 2011).

Other studies report that in high-risk processes of change there is a reduced sense of well-being, higher levels of job dissatisfaction and stress, and decreased trust in the organization (Bryson et al., 2013). The negative effects on the well-being of organizational change are associated with assessing job uncertainty and job loss (Green, 2011), worker overload and stress (Dahl, 2011; Green, 2011), increased anxiety (Bryson et al., 2013) and threat assessments are positively related to absenteeism, inertia, and voluntary terminations (Fugate et al., 2012). In this case, change management practices can affect the work environment and cause positive affect on individuals. Based on this context, we propose hypotheses 3, 4, 5, and 6:

- Hypothesis 3: Change management practices are positively associated with the well-being of individuals at work.

- Hypothesis 4: The reasons for change and the perceived benefits of change positively affect the well-being of individuals at work.

- Hypothesis 5: The reasons and benefits of change mediate the association between change management practices and the well-being of individuals at work. 
- Hypothesis 6: The reasons and benefits of change mediate the association between change management practices and supportive behaviors for change.

Thus, the aim of the present study was to identify the factors that influence supportive behaviors and the well-being of individuals during processes of change by relating the variables of change management practices and reasons and benefits for change as antecedents of behavior. In view of the discussion above, the study focused on the following specific objectives:

- Describing change management practices, reasons, and benefits for change, change-supportive behavior, and well-being at work of employees from Brazilian organizations considering the context of change.

- Testing to what extent change management practices, reasons and benefits for change predict change-supportive behavior, and well-being at work of employees from Brazilian organizations considering the context of change.

- Testing to what extent reasons and benefits for change mediate the relationship between change management practices and the criteria for well-being at work and employee supportive behaviors from a Brazilian organization in a context of change.

\section{METHOD}

\subsection{Organizational context and changes}

The study was conducted at a Brazilian holding company that consists of transportation companies from southeastern and southern Brazil with approximately 8,000 employees. Currently, the holding is undergoing changes related to the expansion of the scope of the services provided, organizational redesign, region of operation and headquarters. Examples of change include the creation of a logistics center; incorporation of logistics, charter and tourism services; inclusion of human resources departments and personnel department; and the change of headquarters, migrating from Rio de Janeiro to São Paulo.

\subsection{Participants}

A total of 255 employees from five holding-company units participated in the study. The sample represents about $30 \%$ of the population of the 
company's administrative staff. All employees who were directly involved in the process of organizational change were invited to participate in the study.

\subsection{Instruments}

Study participants were invited to participate by the researchers and were sent a link from the research instruments to the scales for assessing change management practices, the reasons and benefits for change, supportive behaviors during organization change, and well-being at work. The instruments contained a consent form, confidentiality assurance form and questions to assess demographic data. The instruments were available for 15 days for the company participants using the Survey Monkey platform. The following items describe the scales, dimensions and available validity studies.

- Change management practices: to assess the five organizational change practices (diagnosis and alignment, leadership, communication, compensation and incentives, and training), we used the Organizational Change Management Practices Assessment Questionnaire (20 items) for recipients of change with evidence of validity found by Raineri (2011). The scale was adapted to Brazilian Portuguese by Machado and Neiva (2017) and content validity indexes were tested on a sample of workers from several Brazilian organizations. In the sample of the present research, the instrument was submitted to exploratory and CFA, totaling 20 items in the instrument. The factor loadings were above 0.50 and Cronbach's alpha was 0.95 and the fit measures were adequate $\left(\chi^{2} / \mathrm{df}=2.849 ; \mathrm{CFI}=0.91 ; \mathrm{RMSEA}=0.09\right)$, indicating good validity indexes of the instrument.

- Reasons and benefits for change: these are two one-factor scales composed of 7 and 9 items. In the sample of the research, the exploratory and confirmatory factor analyses of the reasons for change Reasons for Organizational Change (ROC) scale presented a single factor structure and its 7 items assess the occurrence of responses related to the perception of employees concerning the reasons and organization's reasons for the change. The factor loadings were above 0.50 and Cronbach's alpha was 0.89 and the fit measures were adequate $\left(\chi^{2} / \mathrm{df}=\right.$ 3.79; GFI $=0.91$; CFI $=0.91$; RMSEA $=0.07$, which were similar to the results of the original instrument (Kim et al., 2011). Examples of the items in the Organizational Change Benefits (OCB): "The organization must change to be more competitive in the market". 
According to the results of the present sample, the second unifactorial scale verifies the perceived benefits of organizational change (OCB). It has a unifactorial structure and the 10 items assess the occurrence of responses connected to the perception of individuals of the benefits and opportunities following organizational change. The factor loadings were above 0.50, Cronbach's alpha was 0.91 and fit measures were adequate $\left(\chi^{2} / \mathrm{df}=3.73 ; \mathrm{GFI}=0.90 ; \mathrm{CFI}=0.93 ; \mathrm{TLI}=0.91 ; \mathrm{RMSEA}=0.12\right)$. Example of an item in the OCB: "Organizational change will increase salaries and bring benefits to me".

- Supportive behaviors during organization change: it is a scale that evaluates behavioral reactions to change based on the model proposed by Nery and Neiva (2015). It has a bifactorial structure and 9 items that assess the occurrence of supportive behavioral responses to change. The "change-support behavior" factor included behaviors that are desired during the process of change. The results of the present sample reveal factor loadings above 0.50 , Cronbach's alpha of 0.92 and the fit measures for CFA were adequate $\left(\chi^{2} / \mathrm{df}=1.83\right.$; $\mathrm{TLI}=0.93$; $\mathrm{CFI}=0.94$; GFI $=$ 0.90 ; RMSEA $=0.06)$. Example item: "I behave in a favorable way to change". In this study, only the items of the change-supportive behavior factor were used.

- Well-being at work: the Well-being at Work Scale (Paschoal \& Tamayo, 2008; Demo \& Paschoal, 2016) consist of 3 factors (positive affect, negative affect, and fulfillment) and 29 items. The results of exploratory and CFA revealed three factors with Cronbach's alpha of $0.91,0.86$ and 0.87 and factor loadings above 0.45 . The fit measures for CFA were also adequate $\left(\chi^{2} / \mathrm{df}=2.02\right.$; TLI $=0.91$; CFI $=0.92$; GFI $=0.90$; RMSEA $=0.07)$.

\subsection{Collection procedure and data analysis}

The instruments were applied to employees and unit managers using an electronic form available on the internet. E-mails were sent to employees inviting them to participate and the application ensured representativity of participants per unit affected by the interventions. First, we verified the existence of omitted and extreme cases using multicollinearity and singularity analyses and other assumptions, such as normality, linearity, homoscedasticity. Missing cases were replaced by the item mean as they reached values below 5\% of cases (Tabachinick \& Fidel, 2013) and were evaluated as random. Data from this sample were submitted to EFA to verify 
how the set of variables correlated and whether the structure of the instruments presented the number of intrinsic factors of the original scales. The consistency of the factors was assessed by Cronbach's alpha. After determining the number of factors, the main extraction method used was the Axis Factoring (Promax rotation) to perform factor analysis. The CFA of the instruments was also performed using exploratory factor analysis. Data on change-supportive behavior variables, well-being at work, change management practices, and the reasons and benefits for change were analyzed using descriptive statistics; correlations and the theoretical model were tested using structural equations for testing direct or moderate relationships. For analysis of mediation data, the analysis proposed by Hayes (2017), Kline (2016), Kenny and Judd (2014), Ato and Vallejo (2011), and Preacher, Zyphur, and Zhang (2010) was used.

The following assumptions for regression will be analyzed using residual plots, normal probability plots, and statistical tests: phenomenon linearity, constant variance of error terms (homoscedasticity), independence of error terms, and normality of distribution of error term. Finally, multicollinearity and singularity analyses did not indicate problems in the sample researched, i.e., tolerance values were greater than 0.1 and Variance Inflation Factor (VIF) values were lower than 10.0 (Tabachnick \& Fidel, 2013).

To test the influence of the common variance of the method, we used a single factor model that showed no adjustment fitting (NFI $=0.52$; CFI $=$ 0.49 and NNFI $=0.52$ ). The single factor model was used to evaluate whether there was an effect of common variance of the method in the research results (Podsakoff, MacKenzie, Lee, \& Podsakoff, 2003). When there was no adjustment in the model, it was concluded that the common variance of the method did not explain the results.

\section{RESULTS}

First the means, deviations and correlations among the research variables were calculated. The data in Figure 7.1 show that the research variables are associated with each other, which may indicate that the research hypotheses may be corroborated. 


\section{(Figure 7.1)}

DESCRIPTIVE DATA AND CORRELATIONS AMONG THE VARIABLES

OF THE RESEARCH

\begin{tabular}{|c|c|c|c|c|c|c|c|c|c|}
\hline \multirow[b]{2}{*}{ Variable } & \multirow[b]{2}{*}{ Mean } & \multirow[b]{2}{*}{$\mathrm{SP}$} & \multicolumn{7}{|c|}{ Correlations } \\
\hline & & & Practices & Reasons & Benefits & $\begin{array}{l}\text { Change- } \\
\text { supportive } \\
\text { behavior }\end{array}$ & Fulfillment & $\begin{array}{l}\text { Positive } \\
\text { affect }\end{array}$ & $\begin{array}{c}\text { Negative } \\
\text { affect }\end{array}$ \\
\hline Practices & 4.82 & 1.37 & 1 & $0.360^{\star \star}$ & $0.506^{\star \star}$ & $0.414^{\star \star}$ & $0.453^{\star \star}$ & $0.457^{\star \star}$ & $-0.445^{\star \star}$ \\
\hline Reasons & 5.75 & 0.85 & $0.360^{\star \star}$ & 1 & $0.539^{\star \star}$ & $0.411^{\star \star}$ & $0.229^{\star *}$ & $0.264^{\star \star}$ & -0.139 \\
\hline Benefits & 5.63 & 1.22 & $0.506^{\star \star}$ & $0.539^{\star \star}$ & 1 & $0.433^{\star \star}$ & $0.473^{\star \star}$ & $0.488^{\star \star}$ & $-0.305^{\star \star}$ \\
\hline Support & 6.12 & 0.88 & $0.414^{\star \star}$ & $0.411^{\star \star}$ & $0.433^{\star \star}$ & 1 & $0.458^{\star \star}$ & $0.425^{\star \star}$ & $-0.332^{\star \star}$ \\
\hline Fulfillment & 4.35 & 0.66 & $0.453^{\star \star}$ & $0.229^{\star \star}$ & $0.473^{\star \star}$ & $0.458^{\star *}$ & 1 & $0.561^{\star \star}$ & $-0.243^{\star \star}$ \\
\hline $\begin{array}{l}\text { Positive } \\
\text { effects }\end{array}$ & 3.74 & 0.9 & $0.457^{\star \star}$ & $0.264^{\star \star}$ & $0.488^{\star \star}$ & $0.425^{\star *}$ & $0.561^{\star \star}$ & 1 & $-0.471^{\star \star}$ \\
\hline $\begin{array}{l}\text { Negative } \\
\text { effects }\end{array}$ & 2.31 & 0.93 & $-0.445^{\star \star}$ & -0.139 & $-0.305^{\star \star}$ & $-0.332^{\star \star *}$ & $-0.243^{\star \star}$ & $-0.471^{\star \star}$ & 1 \\
\hline
\end{tabular}

** Significant correlations at $p=0.001$.

Source: Elaborated by the authors.

To evaluate the hypothesized relationships in the research, two models were tested using structural equations with the variables well-being at work and change-supportive behaviors as criterion variables. The first models used the items and factor structures of the instruments; however, these results did not reach satisfactory adjustment indices (Chi-square ratio and degrees of freedom were below 5, but the GFI, CFI, NFI, and TLI indices were below 0.90). To improve adjustments, however, we opted to use the factor scores of the variablesto test the relationships.

In the first model tested (Figure 7.2), change-supportive behavior was included as a response variable and in the second model (Figure 7.3), wellbeing at work was included as a response variable. 


\section{(Figure 7.2)}

RELATIONSHIPS BETWEEN CHANGE MANAGEMENT PRACTICES, REASONS AND BENEFITS, AND CHANGE-SUPPORTIVE BEHAVIOR

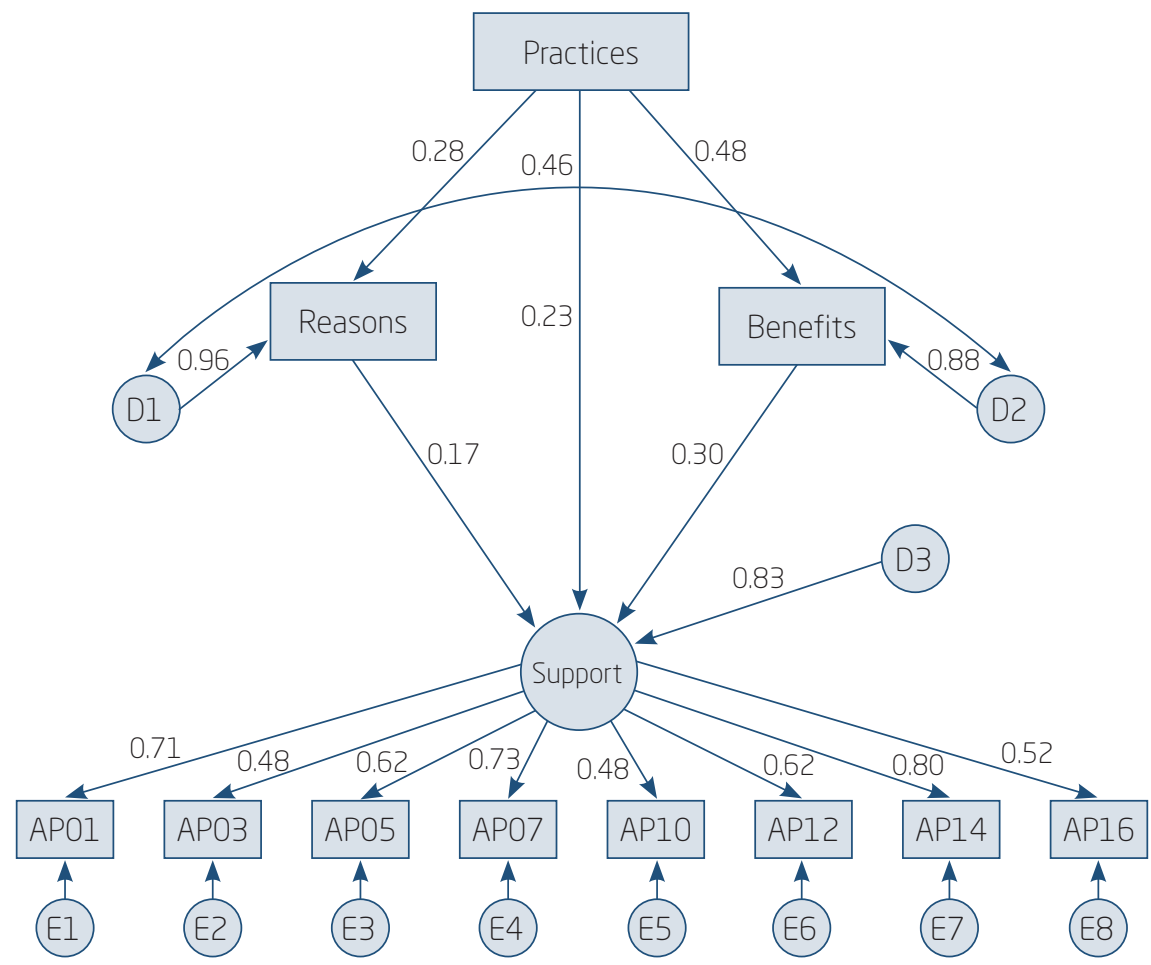




\section{(Figure 7.3)}

\section{RELATIONSHIPS BETWEEN CHANGE MANAGEMENT PRACTICES, REASONS AND BENEFITS, AND WELL-BEING AT WORK}

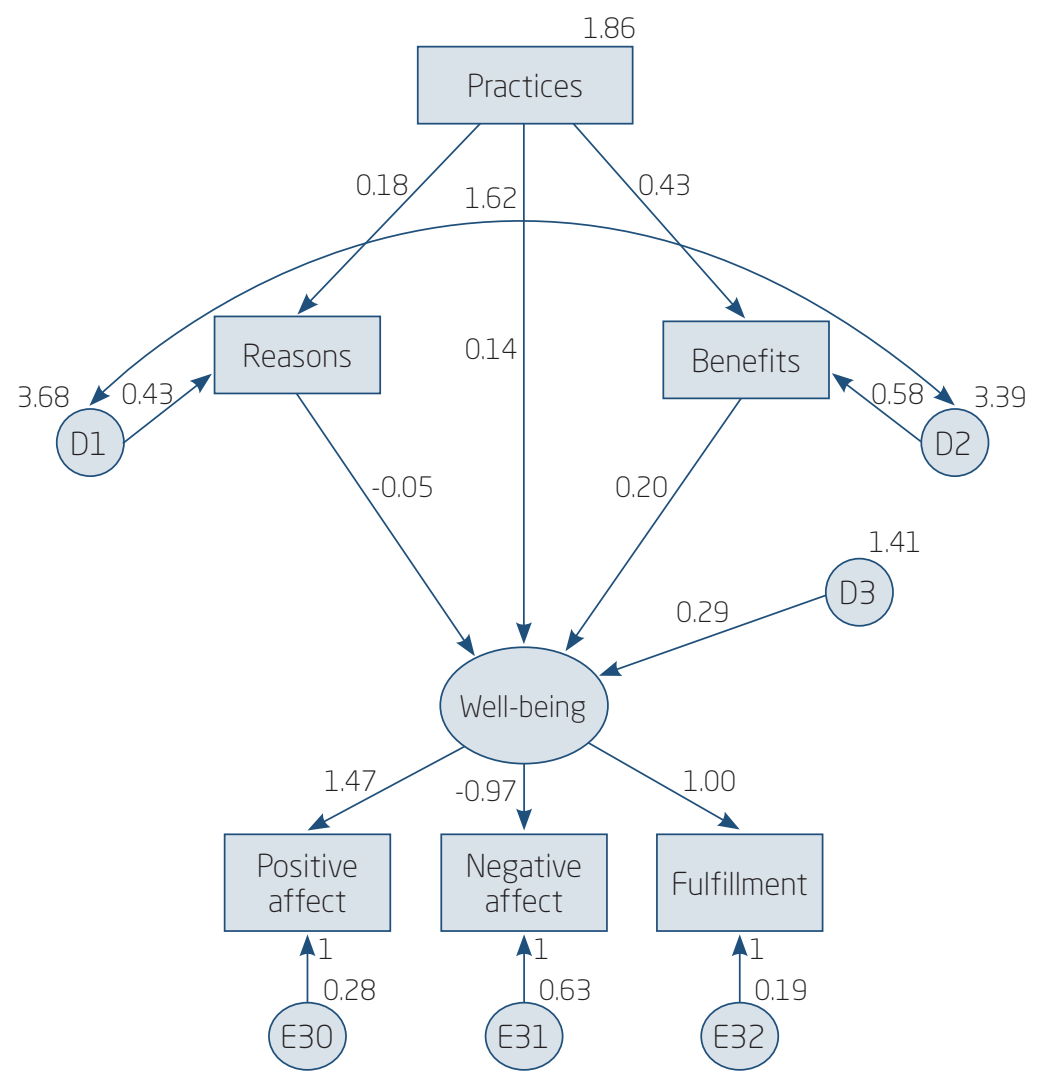

According to the results shown in Figure 7.4, the tested models presented good fit indices and the model that predicts supportive behavior presented more robust indices $(\mathrm{GFI}=0.97$; $\mathrm{CFI}=0.95)$ and lower residual values $($ RMSEA $=0.076)$. The model that predicts well-being at work still has high residue values $($ RMSEA $=0.12)$, considering the overall assessment. 


\section{(Figure 7.4)}

INDEX OF MODEL SUITABILITY

\begin{tabular}{cccccccccc}
\hline & $\chi^{\prime \prime}$ & d.f. & $\chi^{\prime \prime} \gamma . \lambda$. & NFI & TLI & CFI & GFI & AGFI & $\begin{array}{c}\text { RMSEA } \\
(\text { Cl 95\%) }\end{array}$ \\
\hline Model 1 & 88.50 & 41 & 2.15 & 0.90 & 0.91 & 0.93 & 0.92 & 0.90 & $\begin{array}{c}0.076 \\
(0.054-0.098)\end{array}$ \\
\hline Model 2 & 23.04 & 6 & 3.84 & 0.93 & 0.90 & 0.95 & 0.97 & 0.90 & $\begin{array}{c}0.12 \\
(0.07-0.17)\end{array}$ \\
\hline
\end{tabular}

d.f. $=$ degrees of freedom; $\mathrm{Cl}=$ confidence interval $(95 \%)$.

As for the hypotheses tested, Figure 7.5 shows the coefficients that indicate the results for the tests. Hypothesis 1 was corroborated to the extent that change management practices were positively associated with change-supportive behavior $(\beta=0.23 ; \mathrm{p}=0.000)$. The reasons for change $(\beta=0.17 ; p=0.000)$ and the perceived benefits of change $(\beta=0.30 ; p=$ $0.000)$ were positively associated with the change-supportive behavior. Regarding the second model, change management practices were positively associated with the well-being of individuals at work $(\beta=0.39 ; \mathrm{p}=0.000)$. The reasons for change did not affect well-being at work ( $\beta=-0.082$; ns), but the perceived benefits of change positively affected individuals' wellbeing at work $(\beta=0.49, p=0.000)$.

The assumptions surrounding the mediation tests are shown in Figure 7.5. The reasons and benefits of change mediate the association between change management practices and change-supportive behaviors with indirect effects confirmed by bootstrapping, using the process calculations (Hayes, 2017), and by comparing the restricted and non-restricted models. The process, developed by Hayes (2017), is macro and it tests the mediation models. Organizational reasons for change, on the other hand, did not mediate the relationship between management practices and well-being at work, but the perceived benefits of change mediate the relationship between change management practices and well-being at work. These results are shown in Figure 7.5. 


\section{(Figure 7.5)}

RESULT OF THE MEDIATION TEST FOR THE CRITERION VARIABLE

\begin{tabular}{|c|c|c|c|c|}
\hline \multirow{2}{*}{ Variable } & \multicolumn{2}{|c|}{ Supporting changes } & \multicolumn{2}{|c|}{ Well-being } \\
\hline & $\beta$ & Indirect effect & $\beta$ & Indirect effect \\
\hline Practice-benefits & $0.48^{\star \star}$ & & $0.48^{\star \star}$ & \\
\hline Practice-reasons & $0.28^{\star \star}$ & & $0.28^{\star \star}$ & \\
\hline Practice-criterion variable & $0.23^{\star \star}$ & $0.19^{\star \star}$ & $0.39 * \star$ & $0.21^{\star \star}$ \\
\hline Reasons-criterion variable & $0.17^{\star \star}$ & & $-0.082 n \mathrm{~ns}$ & \\
\hline Benefit-criterion variable & $0.30 * \star$ & & $0.49 * \star$ & \\
\hline
\end{tabular}

** $\mathrm{p} \leq 0.05 ; \mathrm{ns}=$ not significant.

More importantly, the effects of variables on the well-being components were also tested (positive affect, negative affect, and fulfillment). Change management practices had a significant effect on positive affect $(\beta=0.48 ; p=0.000)$, negative affect $(\beta=-0.31 ; p=0.013)$ and fulfillment $(\beta=0.45 ; p=0.000)$. Perceived benefits influenced positive affect $(\beta=$ $0.39 ; p=0.009)$, negative affect $(\beta=-0.25 ; p=0.000)$ and fulfillment $(\beta=0.37 ; p=0.005)$. Perceived organizational reasons, however, presented no significant effect on the well-being components.

\section{DISCUSSION AND CONCLUSION}

The study was designed with the general objective of investigating the relationships between change management practices, reasons and benefits for change, change-supportive behavior and well-being of workers during the process of organizational change. According to the study results, change management practices positively affected both supportive behaviors and well-being of workers. These results corroborate the findings of Vakola (2016) and Kim et al. (2011), regarding the idea that certain actions can promote positive responses and generate well-being and satisfaction during the process. Change management practices can affect individuals as they involve actions of employee diagnosis, mobilization and preparation, which can shape the point of view regarding change (Vakola, Tsaousis \& Nikolaou, 2004), and they tend to reduce unfavorable attitudes and minimize the 
perception of the degree of uncertainty (Rafferty \& Griffin, 2006; Devos, Buelens, \& Bouckenooghe, 2007).

The major contribution of this study is related to the differentiated effect of perceived organizational reasons and perceived benefits on supportive behaviors and well-being at work. The reasons for change $(\beta=0.17$, $p=0.000)$ and perceived benefits from change $(\beta=0.30, p=0.000)$ were positively associated with the change-support behavior. However, the reasons for change and benefits of change do not equally influence the well-being of individuals during the processes of change. The reasons for change do not affect well-being at work $(\beta=-0.082 ; n s)$, but the perceived benefits of change positively affect individuals' well-being at work $(\beta=0.49, \mathrm{p}=0.000)$.

Organizational reasons and perceived benefits for change consistently affect the supportive behavior of individuals, which corroborates the general propositions of theorists (Kim et al., 2011; Oreg et al., 2011; Stensaker \& Langley, 2010; Vakola, 2016; Vakola et al., 2013; Weiner, 2009). Therefore, it may be inferred that the perception of organizational reasons helps attribute meaning ("make sense"), which favors positive behaviors (Kim et al., 2011; Oreg et al., 2011; Vakola et al., 2013). Prior knowledge to assigning meaning to new information (Bartunek et al., 2006) reduces the complexity of information received, allows the association between past actions and meanings (Schwandt, 2005), and helps members accept the need for change (Kim et al., 2011; Vakola, 2016). In the case of benefits, recipients can also measure organizational change in terms of their own perceived or anticipated gains (Kim et al., 2011; Vakola, 2016) or losses as change influences whether the quality of some aspects of their work or work life may improve or not (Vakola, 2016). The reasons are organizational in nature and anticipated benefits of change refer to the expected results of the change in personal valence of employees (Kim et al., 2011; Oreg et al., 2011; Vakola et al., 2013).

However, the effect of organizational reasons and perceived benefits on well-being does not follow the same logic. Organizational reasons may follow the logic of productivity and outcome indicators, which may not include the human aspect of the process of organizational change (Neiva \& Paz, 2012; Oreg et al., 2011; Vakola et al., 2013). Evaluative theories that address the relationship between cognition-emotion-behavior (Fugate et al., 2012) are based on the proposition that individuals evaluate their environments and these evaluations cause emotions, often associated with affective states (Fugate et al., 2012). According to the results of the present study, organizational reasons for change do not contribute to the positive assessment of consequences for the well-being of employees (Bryson et al., 
2013; Dahl, 2011; Fugate et al., 2012). The perceived benefits, in turn, seem to influence positive evaluations that impact both positive affect, negative affect, and fulfillment (Bryson et al., 2013; Fugate et al., 2012). Well-being includes affective and cognitive aspects experienced at work (Dahl, 2011) and can be influenced by organizational change. The implementation of organizational changes is related to the context in which changes occur, to the cognitive traits that the individual uses to interpret them, and the opinion of others about the process (Bryson et al., 2013; Dahl, 2011; Green, 2011). In the case of changes observed in this study, it seems that the organizational reasons were not very favorable for individuals. Thus, this study contributes to the understanding of the factors that influence the reactions of targets to changes, which are still a scarce in this area of study (Oreg et al., 2011).

The analysis of mediation relationships has assumed greater importance in the understanding of social and psychological phenomena. The fifth and sixth hypotheses ( $\mathrm{H} 5$ and $\mathrm{H} 6$ ) suggest that the reasons for change and perceived anticipated benefits mediate the relationship between management practices for change, supportive behaviors, and well-being at work. The reasons and benefits of change mediate the association between change management practices and supportive behaviors, and the indirect effects were confirmed by bootstrapping, process calculations, and the comparison between the constrained and non-constrained models. Organizational reasons for change, on the other hand, do not mediate the relationship between management practices and well-being at work, but the perceived benefits of change mediate the relationship between change management practices and well-being at work. These results were shown in Figure 7.5. Again, the organizational reasons for change do not mediate the relationships between management practices and supportive behaviors and well-being. A possible explanation for this may be the idea that perceived organizational aspects do not contribute to the attribution of meaning that affect cognition and the negative and positive affects related to change. The benefits are more individual, which would facilitate the influence on these aspects (Bryson et al., 2013; Dahl, 2011; Green, 2011).

The mediation model of the study is considered complex because it has more than one variable as a mediator (Preacher et al., 2010). Thus, we assessed mediation verification using structural equations, and we calculated the magnitude and significance of the indirect effects by bootstrapping. Indirect effects are estimated from a population sample and are the products of regression coefficient estimates. Significant indirect effects are a measure analogous to other methods that indicate the significance of regression 
interaction effects (Preacher \& Selig, 2012). For this, several sub-model analyses were performed to verify the sign, magnitude and significance of the coefficients, as well as to verify the mediation relationship (Preacher \& Selig, 2012; Preacher et al., 2010). These effects were corroborated by the bootstrapping analysis.

\section{PRACTICAL IMPLICATIONS, LIMITATIONS, AND FURTHER STUDIES}

Considering that the literature has few studies that investigate the actions performed during the process of change and how they affect the affective, cognitive and behavioral reactions of individuals (Rafferty \& Griffin, 2006; Oreg et al., 2011; Vakola, Tsaousis, \& Nikolaou, 2004), the theoretical contribution of this study was to measure these actions and measure the aspects that contribute to the attribution of meaning by individuals during the process of change.

Large-scale change processes are only successful if there is behavioral change of members of an organization (Santos, Neiva, \& Andrade-Melo, 2013). Therefore, understanding how attitudes influence change-supportive behavior and well-being at work is a successful differentiator. Finally, this study can help human resources management think about actions to be developed, mainly, diagnostic actions, leadership mobilization, communication and preparation that disseminate the stages of the process of change and improve the transparency of the processes, fostering positive attitudes and promoting engagement in the proposed process of change (Franco, Neiva, Nery, \& Demo, 2016).

The research was limited to a cross-sectional study, but studies on organizational change are usually conducted when the process is already underway. Despite this methodological limitation, longitudinal surveys during the initial phase of change should be carried out, as they make it possible to analyze the entire process of organizational change as well as its consequences. The results allow to compare the process and to estimate better the impacts of change on employees.

The sample of this research can also be considered a limiting factor, given that it was from a single private organization. The internal context of change may have different characteristics in other sectors in which market pressure is less constant and affect change differently. Further studies are needed to broaden the results and include other sectors to reach more general conclusions. 


\section{PRÁTICAS DE GESTÃO, BEM-ESTAR E COMPORTAMENTO DE APOIO}

\section{RESUMO}

Objetivo: Esse artigo tem por objetivo avaliar a influência das práticas de gestão da mudança, das razões e dos benefícios sobre o bem-estar e o comportamento de apoio às mudanças.

Originalidade/valor: A contribuição teórica deste estudo está em subsidiar a mensuração das ações realizadas, as reações dos indivíduos ao processo e a mensuração dos aspectos que contribuem para a atribuição de sentido que os indivíduos fazem sobre o processo de mudança.

Design/metodologia/abordagem: Participaram do estudo 255 colaboradores administrativos de uma holding brasileira que oferece serviços de transporte rodoviário, de fretamento e logística em três estados do Brasil. Foram utilizadas as seguintes medidas: Escala de Práticas de Gestão da Mudança, Escala de Razões e Benefícios para a Mudança, Instrumento de Comportamentos de Apoio à Mudança Organizacional e Escala de Bem-Estar no Trabalho. Os instrumentos foram aplicados aos profissionais e aos gestores das unidades para avaliar as medidas propostas considerando um processo de mudança pelo qual a organização estava passando. Os dados da amostra foram submetidos à análise fatorial exploratória (AFE) e análise fatorial confirmatória (AFC) dos instrumentos, além da análise de mediação e de equações estruturais para o teste de hipóteses.

Resultados: Os resultados do estudo apontam que as práticas de gestão da mudança afetam positivamente tanto os comportamentos de apoio quanto o bem-estar do trabalhador. Foi identificado também efeito diferenciado das razões organizacionais percebidas e dos benefícios percebidos nos comportamentos de apoio e no bem-estar no trabalho.

\section{PALAVRAS-CHAVE}

Mudança nas organizações. Práticas de gestão. Bem-estar do trabalhador. Razões e benefícios com a mudança. Apoio à mudança. 


\section{REFERENCES}

Afande, F. O. (2015). Factors that influence organizational transformation: A case of life insurance companies in Kenya. Journal of Marketing and Consumer Research, 8, 111-142.

Ato, M., \& Vallejo, G. (2011). Los efectos de terceras variables en la investigación psicológica. Anales de Psicologia, 27(2), 550-561. Retrieved from http://www.redalyc.org/articulo.oa?id=16720051031

Bartunek, J. M., Rousseau, D. M., Rudolph, J., \& Depalma, J. (2006). On the receiving end: Sensemaking, emotion, and assessments of an organizational change initiated by others. Journal of Applied Behavioral Science, 42 (2), 182-206. doi:10.1177/0021886305285455

Battilana, J., Gilmartin, M., Sengul, M., Pache, A.-C., \& Alexander, J. (2010). Leadership competences for implementing planned organizational change. Leadership Quarterly, 21(3): 422-438. doi:10.1016/j.leaqua.2010.03.007

Bryson, A., Barth E., \& Dale-Olsen, H. (2013). The effects of organizational change on worker well-being and the moderating role of trade unions. Industrial and Labor Relations Review, 66 (4), 989-1011. doi:10.1177/00197 9391306600410

Buchanan, D., Fitzgerald, L., Ketley, D., Gollop, R., Jones, J. L., Lamont, S. S., $\&$ Whitby, E. (2005). No going back: A review of the literature on sustaining organizational change. International Journal of Management Reviews, 7(3), 189-205. doi:10.1111/j.1468-2370.2005.00111.x

Burke, R. J., \& Greenglass, E. R. (2000). Hospital restructuring and nursing staff well-being: The role of coping. International Journal of Stress Management, 7(1), 49-59. doi:10.1023/A:1009566715728

Burke, W. W. (2011). A perspective on the field of organization development and change: The Zeigarnik effect. Journal of Applied Behavioral Science, 47(2), 143-167. doi:10.1177/0021886310388161

Carter, A., Armenakis, A., Field, H. S., \& Mossholder, K. W. (2013.) Transformational leadership, relationship quality, and employee performance during continuous incremental organizational change. Journal of Organizational Behavior, 34(7), 942-958. doi:10.1002/job.1824

Cunningham, G. B. (2006). The relationships among commitment to change, coping with change, and turnover intentions. European Journal of Work and Organizational Psychology, 15(1), 29-45. doi:10.1080/13594320500418766 
Dahl, M. S. (2011). Organizational change and employee stress. Management Science, 57(2), 240-256. doi:10.1287/mnsc.1100.1273

Davis, J., \& Holland, T. (2002). The challenge of global change for strategy: Opportunities for charting a new course. In A. H. Shrivastava \& J. Dutton (Eds.). Advances in strategic management: Responding to a changing world (pp. 99-142). Greenwich: Jai Press.

Devos, G., Buelens, M., \& Bouckenooghe, D. (2007). Contribution of content, context, and process to understanding openness to organizational change: two experimental simulation studies. The Journal of Social Psychology, 147(6), 607-629. doi:10.3200/SOCP.147.6.607-630

Franco, K. S., Neiva, E. R., Nery, V. de F., \& Demo, G. (2016). The relationship between context, attitudes and well-being in organizational change. Psicologia: Teoria e Pesquisa, 32(spe), e32ne219. Epub March 27, 2017. doi:10.1590/0102-3772e32ne219

Fugate, M., Kinicki, A. J., \& Prussia, G. P. (2008). Employee coping with organizational change: An examination of alternative theoretical perspectives and models. Personnel Psychology, 61, 1-36. doi:10.1111/j.1744-6570. 2008.00104.x

Fugate, M., Prussia, G. E., \& Kinicki, A. J. (2012). Managing employee withdrawal during organizational change: The role of threat appraisal. Journal of Management, 38(3), 890-914. doi:10.1177/0149206309352881

Green, F. (2011). Unpacking the misery multiplier: How employability modifies the impacts of unemployment and job insecurity on life satisfaction and mental health. Journal of Health Economics, 30(2), 265-276. doi:10.1016/j.jhealeco.2010.12.005

Hayes, A. F. (2017). Introduction to mediation, moderation, and conditional process analysis: A regression based approach (2. ed.). New York: The Guilford Press.

Hayes, J. (2002). The theory and practice of change management. New York: Palgrave Macmillan.

Hayes, J. (2007). Evaluating a leadership development program. Organization Development Journal, 25(4), 89-94.

Herscovitch, L., \& Meyer, J. P. (2002). Commitment to organizational change: Extension of a three-component model. Journal of Applied Psychology, 87(3), 474-487. doi:10.1037/0021-9010.87.3.474

Jansson, N. (2013). Organizational change as practice: A critical analysis. Journal of Organizational Change Management, 26(6), 1003-1019. doi:10.1108/ JOCM-09-2012-0152 
Jian, G. (2011). Articulating circumstance, identity and practice: Toward a discursive framework of organizational changing. Organization, 18(1), 45-64. doi:10.1177/1350508410373672

Kenny, D. A., \& Judd, C. M. (2014). Power anomalies in testing mediation. Psychological Science, 25, 334-339. doi:10.1177/0956797613502676

Kim, T. G., Hornung, S., \& Rousseau, D. M. (2011). Change-supportive employee behavior: Antecedents and the moderating role of time. Journal of Management, 37(4), 1664-1693. doi:10.1177/0149206310364243

Kline, R. B. (2016). Principles and practice of structural equation modeling (4. ed.) New York: Guilford Press.

Kotter, J. P. (2000). Liderando mudança (3. ed.). Rio de Janeiro: Campus.

Levay, C. (2010). Charismatic leadership in resistance to change. The Leadership Quarterly, 21 (1), 127-143. doi:10.1016/j. leaqua.2009.10.010

Lysova, E., Richardson, J., Khapova, S., \& Jansen, P. (2015). Changesupportive employee behavior: A career identity explanation. Career Development International, 20(1), 38-62. doi:10.1108/CDI-03-2014-0042

Machado, L. C. P., \& Neiva, E. R. (2017). Práticas de gestão da mudança: Impacto nas atitudes e nos resultados percebidos. Revista Psicologia: Organizações e Trabalho, 17(1), 22-29. doi:10.17652/rpot/2017.1.12157

Morin, A. J., Meyer, J. P., Bélanger, É., Boudrias, J. S., Gagné, M., \& Parker, P. D. (2016). Longitudinal associations between employees' beliefs about the quality of the change management process, affective commitment to change and psychological empowerment. Human Relations, 69(3), 839-867. doi:10.1177/0018726715602046

Neiva, E. R., \& Paz, M. T. (2012). Percepção de mudança individual e organizacional: O papel das atitudes, dos valores, do poder e da capacidade organizacional. Revista de Administração, 47(1), 22-37. doi:10.5700/rausp 1023

Nery, V. F., \& Neiva, E. R. (2015). Variáveis de contexto e respostas à mudança organizacional: Testando o papel mediador das atitudes. Psicologia: Teoria e Pesquisa, 31 (2), 259-268. doi:10.1590/0102-37722015021968259268

Oreg, S., Vakola, M., \& Armenakis, A. (2011). Change recipients' reactions to organizational change: A 60-year review of quantitative studies. The Journal of Applied Behavioral Science, 47(4), 461-524. doi:10.1177/0021 886310396550 
Paschoal, T., \& Tamayo, A. (2008). Construção e validação da Escala de Bem-Estar no Trabalho. Avaliação Psicológica, 7(1), 11-22. Retrieved from http://www.redalyc.org/articulo.oa?id=335027183004

Pearce, C. L., \& Sims, H. P. (2002). Vertical versus shared leadership as predictors of the effectiveness of change management teams: An examination of aversive, directive, transactional, transformational and empowering leader behaviors. Group Dynamics: Theory, Research, and Practice, 6(2), 172-197. doi:10.1037//1089-2699.6.2.172

Podsakoff, P. M., MacKenzie, S. B., Lee, J., \& Podsakoff, N. P. (2003). Common method biases in behavioral research: A critical review of the literature and recommended remedies. Journal of Applied Psychology, 88(5), 879-903. doi:10.1037/0021-9010.88.5.879

Preacher, K. J., \& Selig, J. P. (2012). Advantages of Monte Carlo confidence intervals for indirect effects. Communication Methods and Measures, 6, 77-98. doi:10.1080/19312458.2012.679848

Preacher, K. J., Zyphur, M. J., \& Zhang, Z. (2010). A general multilevel SEM framework for assessing multilevel mediation. Psychological Methods, 15, 209-233. doi:10.1037/a0020141

Puspasari, N., Sukmawati, A., \& Sumertajaya, I. (2017). Leadership style, organizational Communication, and employee participation to increase employee readiness in facing changes in business environment. Journal of Applied Management, 15(4), 651-658. doi:10.21776/ub.jam2017.015.04.12

Rafferty, A. E., \& Restubog, S. L. D. (2010). The impact of change process and context on change reactions and turnover during a merger. Journal of Management, 36(5), 1309-1338. doi:10.1177/0149206309341480

Rafferty, A. E., \& Griffin, M. A. (2006). Perceptions of organizational change: A stress and coping perspective. Journal of Applied Psychology, 91 (5), 11541162. doi:10.1037/0021-9010.91.5.1154

Raineri, A. B. (2011). Change management practices: Impact on perceived change results. Journal of Business Research, 64(3), 266-272. doi:10.1016/j. jbusres.2009.11.011

Rao, M. S. (2015). The tools and techniques of effective change management: Why some reformers succeed while others fail. Human Resource Management International Digest, 23(1), 35-37. doi:10.1108/ HRMID-12-2014-0163

Sande, O. A., Walela, K. B., \& Wamukoya, O. (2015). Change management and performance of public secondary schools in Siaya sub county. International Journal of Scientific \& Technology, 4(4), 162-174. 
Santos, J. N., Neiva, E. R., \& Andrade-Melo, E. A. (2013). Relação entre clima organizacional, percepção de mudança organizacional e satisfação do cliente. Psicologia: Teoria e Pesquisa, 29(1), 31-39.

Schreyögg, G., \& Sydow, J. (2011). Organizational path dependence: A process view. Organization Studies, 32(3), 321-335. doi:10.1177/017084 0610397481

Schwandt, D. R. (2005). When managers become philosophers: Integrating learning with sensemaking. Academy of Management Learning \& Education, 4(2), 176-192. Retrieved from http://www.jstor.org/stable/40214286

Stensaker, I., \& Meyer, C. (2012). Change experience and employee reactions: Developing capabilities for change. Personnel Review, 41(1), 106-124. doi:10.1108/00483481211189974

Stensaker, I. G., \& Langley, A. (2010). Change management choices and trajectories in a multidivisional firm. British Journal of Management, 21 (1), 7-27. doi:10.1111/j.1467-8551.2009.00657.x

Tabachnick, B. G., \& Fidell, L. S. (2013). Using multivariate statistics (6. ed.). Boston: Pearson.

Vakola, M. (2016). The reasons behind change recipients' behavioral reactions: a longitudinal investigation. Journal of Managerial Psychology, 31 (1), 202-215. doi:10.1108/JMP-02-2013-0058

Vakola, M., Tsaousis, I., \& Nikolaou, I. (2004). The role of emotional intelligence and personality variables on attitudes toward organisational change. Journal of Managerial Psychology, 19(2), 88-110. doi:10.1108/026 83940410526082

Vakola, M., Armenakis, A., \& Oreg, S. (2013). Reactions to organizational change from an individual differences perspective: A review of empirical research. In S. Oreg, A. Mitchel, \& R. Todnem By (Eds.). The psychology of organizational change: Viewing change from the employee's perspective (pp. 95-122). Cambridge: Cambridge University Press.

Weiner, B. J. (2009). A theory of organizational readiness for change, Implementation Science, 4(67), 1-9. doi:10.1186/1748-5908-4-67

Whittle, A., Suhomlinova, O., \& Mueller, F. (2010). Funnel of interests: The discursive translation of organizational change. The Journal of Applied Behavioral Science, 46(1), 16-37. doi:10.1177/0021886309357538

Woodman, R. W. (2014). The science of organizational change and the art of changing organizations. Journal of Applied Behavioral Science, 50, 463-477. doi:10.1177/0021886314550575 


\section{AUTHOR NOTES}

Elaine R. Neiva, Ph.D. by the Postgradute Program in Psychology, Brasília University (UnB); Magno O. Macambira, Ph.D. by the Postgradute Program in Psychology, Federal University of Bahia (UFBA); Elisa M. B. A. Ribeiro, Ph.D. by the Postgradute Program in Psychology, Federal University of Bahia (UFBA).

Elaine R. Neiva is now assistant professor 4 of higher education at the Institute of Psychology of Brasília University (UnB); Magno O. Macambira is now assistant professor at the Department of Humanities and Philosophy (DCHF) of State University of Feira de Santana (UEFS); Elisa M. B. A. Ribeiro is now professor at the Postgradute Program in Psychology (PPGP) of Salgado de Oliveira University (Universo).

Correspondence concerning this article should be addressed to Elaine R. Neiva, ICC SUL campus Darcy Ribeiro - Instituto de Psicologia - Departamento de Psicologia Social e do Trabalho, Asa Norte, Brasília, Distrito Federal, Brazil, CEP 24030-060.

E-mail: elaine_neiva@uol.com.br

\section{EDITORIAL BOARD}

Editors-in-chief Janette Brunstein

Silvia Marcia Russi de Domênico

Associated Editor

Mary Sandra Carlotto

Technical Support

Vitória Batista Santos Silva

\section{EDITORIAL PRODUCTION}

Publishing Coordination

Jéssica Dametta

Editorial Intern

Paula Di Sessa Vavlis

Language Editor

Daniel de Almeida Leão
Layout Designer

Emap

Graphic Designer

Libro 